\title{
ANALISIS KESALAHAN BERBAHASA DALAM BAHASA ARAB
}

\author{
Nurkholis \\ Institut Agama Islam Negeri Metro \\ Jl. Ki Hajar Dewantara 15A Iring Mulyo Kota Metro \\ kholisn43@yahoo.com
}

\begin{abstract}
In language activities often have errors, this is due to some problems that exist in the first and second language. Some student do not realize that the language used still has many errors. These errors are not only physical, but also a sign of imperfect knowledge and mastery of the code. The student has not yet internalized the (second) language rules they are learning. With held error analysis is expected the language learners at any level can minimize errors in his language. Analysis of language errors is a process based on analyzing the error of a learned person with an object (language) that has been targeted. The targeted language can be either the mother tongue or the target language.
\end{abstract}

Keyword : An Analysis of error, Language

\begin{abstract}
Abstrak
Dalam kegiatan berbahasa sering terdapat kesalahan, ini disebabkan beberapa masalah yang ada pada kemampuanpenggunaan bahasa pertama dan bahasa kedua. Beberapa pembelajar tidak menyadari bahwa bahasa yang digunakan masih memiliki banyak kesalahan. Pelanggaran dalam kesalahan ini bukan hanya bersifat fisik, melainkan juga merupakan tanda kurang sempurnanya pengetahuan dan penguasaan terhadap kode. Si pembelajar bahasa belum menginternalisasikan kaidah bahasa (kedua) yang dipelajarinya.Dengan diadakan analisis kesalahan diharapkan para pembelajar bahasa di tingkat manapun dapat meminimalkan kesalahan dalam bahasanya. Analisis kesalahan bahasa adalah suatu proses yang didasarkan pada analisis kesalahan orang terpelajar dengan suatu objek (bahasa) yang telah ditargetkan. Bahasa yang ditargetkan dapat berupa bahasa ibu atau bahasa target.
\end{abstract}

Kata Kunci : Analisis Kesalahan, Bahasa

\section{Pendahuluan}

Bahasa Arab dalam pengucapannya bagi kalangan non-Arab ('ajam) secara umum masih terkesan sulit dan rumit, padahal secara linguistic, setiap bahasa di dunia ini memiliki dua sisi berbeda yaitu sisi kesulitan dan kemudahannya sekaligus. Hal ini tergantung pada karakteristik (khashais) system bahasa itu sendiri, baik dari segi fonologi, morfologi, maupun sintaksis dan semantiknya. Seperti halnya Bahasa Arab adalah termasuk bahasa yang pelafalan kata-katanya selalu konsisten, karena sistematis, meskipun demikian, bagi kalangan pelajar Indonesia, kesan "sulit" masih melekat dalam pembelajaran bahasa 
Arab. Hal ini bisa jadi karena perbedaan sistem kebahasaan antara bahasa Arab dan bahasa Indonesia. Pada tataran teoritis, ranah pendalaman bahasa Arab sebagai sebuah sistem, setidak-tidaknya meliputi enam aspek, yatu: bunyi bahasa (fonetik) artikulasi bunyi (fonologi), sharraf (morfologi), nahwu (si ntaksis), al-dalalah(semantik), dan almu'jam (leksikologi). Dalam perspektif linguistik modern, semua aspek tersebut dikaji sebagai sebuah sistem, dalam bingkai dan gradasi yang sistematis, lantas menjadi sebuah disiplin ilmu yang terpisah antara satu dengan lainnya. ${ }^{1}$

Tentunya kita bisa memahami, kalau bahasa Arab dan bahasa Indonesia adalah dua bahasa yang sangat berbeda. Hal yang paling mendasar adalah perbedaan ras bangsa dan rumpun kedua bahasa ini. Bahasa Arab berasal dari rumpun bahasa Semith (Assamiyah), sedangkan bahasa Indonesia dari rumpun bahasa Austronesia. Meski demikian, tidak sedikit kosa kata bahasa Indonesia yang terambil dari bahasa Arab. Bagaimana itu terjadi? Selain karena faktor persinggungan antara orang-orang Indonesia dan Arab, faktor intrinsik bahasa Indonesia sebagai bahasa yang bersifat terbuka terhadap kosa kata asing

${ }^{1}$ Ahmad Muhammad Qaddur, Buhuts $\mathrm{fi}$ al-Isytisyrãq wa al-Lughah, (Muassasah alRisalah, Beirut, cet.I 1996) h. 273 adalah sebab mendasar bahasa Indonesia menerima unsur bahasa lain yang diperlukan, termasuk bahasa Arab. Ada beberapa unsur serapan bahasa Indonesia dari bahasa-bahasa lainya. Selain unsur leksikal, unsur fonem, morfon, dan gramatikal Arab, juga ditengarai turut mempengaruhi serapan dalam bahasa Indonesia.

Pada saat ini banyak pemakai bahasa yang tidak menyadari bahwa bahasa yang digunakan ternyata tidak benar atau masih banyak kesalahan-kesalahan. Dengan diadakan analisis kesalahan maka diharapkan para pembelajar bahasa di tingkat apapun dapat meminimalisir kesalahan dalam berbahasanya.

\section{Pengertian Analisis Kesalahan Berbahasa}

Dalam bukunya yang berjudul "Common Error in Languange Learning" George mengemukakan bahwa kesalahan berbahasa adalah pemakaian bentuk-bentuk tuturan yang tidak diinginkan (unwanted form) khususnya suatu bentuk tutran yang tidak diinginkan oleh penyusun program dan guru pengajaran bahasa.

Bentuk-bentuk tuturan yang tidak diinginkan adalah bentuk-bentuk tuturan yang menyimpang dari kaidah bahasa baku. Hal ini sesuai dengan pendapat Albert Valdman yang mengatakan bahwa yang pertama-tama harus dipikirkan sebelum mengadakan pembahasan tentang berbagai pendekatan dan analisis kesalahan berbahasa 
adalah

menetapkan

standar

penyimpangan atau kesalahan. $^{2}$

Dikemukakan oleh Corder bahwa yang dimaksud dengan kesalahan berbahasa adalah pelanggaran terhadap kode berbahasa. Pelanggaran ini bukan hanya bersifat fisik, melainkan juga merupakan tanda kurang sempurnanya pengetahuan dan penguasaan terhadap kode. Si pembelajar bahasa belum menginternalisasikan kaidah bahasa (kedua) yang dipelajarinya. ${ }^{3}$ Dikatakan oleh Corder bahwa baik penuturan asli maupun bukan penuturan asli sama-sama mempunyai kemungkinan berbuat kesalahan berbahasa. Berdasarkan berbagai pendapat tentang pengertian kesalahan berbahasa yang telah disebutkan di atas, dapatlah dikemukakan bahwa kesalahan berbahasa Indonesia adalah pemakaian bentuk-bentuk tuturan berbagai unit kebahasaan yang meliputi kata , kalimat, paragraf, yang menyimpang dari sistem kaidah bahasa.

Beberapa pandangan terhadap kesalahan berbahasa adalah suatu peristiwa yang bersifat interen dalam setiap pemakaian bahasa baik secara lisan maupun tulisan.

Sebagai seorang guru atau calon seorang guru yang sedang berpraktik

\footnotetext{
${ }^{2}$ Aunurrohman, Belajar dan Pembelajaran, (Bandung: Alfabeta 2011), h. 114

${ }^{3}$ Abdul chear, Linguistik Umum, (Ja karta: Rineka Cipta 2004), h. 77
}

mengajar bahasa Arab, apabila diperhatikan dengan seksama, kita akan menemukan kesalahan-kesalahan yang dibuat siswa. Kesalahan-kesalahan itu ternyata dapat kita pilah dalam dua kategori, Yaitu kategori kesalahan dalam bidang keterampilan dan kesalahan dalam bidang lingustik. Kesalahan yang berhubungan dengan keterampilan terjadi pada saat siswa menyimak, berbicara, membaca, dan menulis. Sedangkan kesalahan dalam bidang linguistik meliputi tata bunyi, tata bentuk kata, dan tata kalimat. ${ }^{4}$

Bahasa Arab merupakan bahasa kedua, pengajaran bahasa Arab dimulai sejak taman kanak-kanak. Ini berarti bahwa pembinaan bahasa telah dimulai sejak dini. Namun ternyata masih banyak terdapat kesalahan dan persoalan dalam berbahasa Arab. Persoalan kebahasaan yang dihadapi dalam pengajaran bahasa Indonesia ialah adanya pengaruh bahasa Ibu. Pengaruh itu ada yang berkaitan dengan tata bunyi, tata bentuk kata, dan ada pula yang berhubungan dengan tata kalimat. ${ }^{5}$

\section{Sumber-Sumber Analisis Kesalahan Berbahasa \\ Proses kesalahan berbahasa berbeda dengan sumber kesalahan berbahasa. Sumber kesalahan berbahasa akan melacak dari mana asal usul kesalahan berbahasa itu; faktor apa yang menyebabkan atau yang mencari

\footnotetext{
${ }^{4}$ Ibid, h. 80

${ }^{5}$ Abdul chear, Linguistik..., h. 186
} 
sumber terjadinya kesalahan berbahasa. Tetapi, proses kesalahan berbahasa akan lebih menekankan bagaimana runtutan perubahan peristiwa dalam kesalahan berbahasa itu dan bukan pada sumber kesalahan.

Dalam pembicaraan tentang topik sumber kesalahan berbahasa, transfer bahasa digunakan sebagai sarana untuk mengetahui sumber kesalahan berbahasa. Sumber kesalahan berbahasa itu ialah bahasa pertama pembelajar maupun bahasa kedua yang sedang di pelajarinya. Transfer bahasa dalam proses kesalahan berbahasa akan berbicara tentang proses terjadinya kesalahan, khususnya yang ditransfer dari bahasa pertama. ${ }^{6}$

Analisis kesalahan berbahasa merupakan sebuah proses yang didasarkan pada analisis kesalahan orang yang sedang belajar dengan objek (yaitu bahasa) yang sudah ditargetkan. Bahasa yang ditargetkan tersebut dapat berupa bahasa ibu maupun bahasa sasaran. Seseorang yang ingin memiliki suatu bahasa tentulah dia harus mempelajarinya. Mempelajari dalam arti melatih berulang-ulang dengan pembetulan diberbagai hal merupakan suatu peristiwa yang wajar ketika mempelajari suatu bahasa.

Analisis kesalahan terutama dikenakan pada bahasa yang sedang Indonesia, (Yogyakarta: CV. Karyo, 1987), h. 22 ditargetkan. Analisis kesalahan sangat berguna sebagai alat pada awal-awal dan selama tingkat-tingkat variasi program pengajaran target dilaksanakan. Tindakan pada pemulaan dapat membuka pikiran guru, perancang khusus bahasa, penulis buku pelajaran atau pun pemerhati bahasa untuk megatasi keruwetan bidang bahasa yang dihadapkan pada siswa.

\section{Penyebab Kesalahan Berbahasa}

Pangkal penyebab kesalahan berbahasa ada pada orang yang menggunakan bahasa bukan pada bahasa yang digunakan. Ada tiga kemungkinan penyebab seseorang salah dalam berbahasa, antara lain $:^{7}$

1. Terpengaruh bahasa yang lebih dulu dikuasainya.

Ini dapat berarti bahwa kesalahan berbahasa dapat disababkan oleh interferensi bahasa ibu atau bahasa pertama (B1) terhadap bahasa kedua (B2) yang sedang dipelajari si pembelajar. Dengan kata lain sumber kesalahan terletak pada perbedaan sistem linguistik B1 dengan sistem linguistik B2.

2. Kekurangpahaman pemakaian bahasa terhadap bahasa yang dipakainya.

Kesalahan yang merefleksikan ciri-ciri umum kaidah bahasa yang dipelajari. Dengan kata lain, salah satu kekeliruan

7 Nanik Setyawati, analisis kesalahan berbahasa indonesia, (Surakarta: Yuma pustaka, 2010), h. 15-16 
dalam menerapkan kaidah bahasa, misalnya : kesalahan generalisasi, aplikasi kaidah bahasa secara tidak sempurna, dan kegagalan mempelajari kondisi-kondisi penerapan kaidah bahasa.

3. Pengajaran bahasa yang kurang tepat atau kurang sempurna.

Hal ini berkaitan dengan bahasa yang diajarkan atau yang dilatihkan dan cara pelaksanaan pengajaran. Bahan pengajar menyangkut masalah sumber, pemilihan, penyususnan, pengurutan, dan penekanan. Cara pengajaran menyangkut masalah pemilihan tektik penyajian, langkah-langkah dan urutan penyajian, intensitas dan kesinambungan pengajaran, dan alatalat bantu dalam pengajaran.

Faktor ketidaktahuan atau tidak diterapkannya kaidah bahasa juga merupakan persoalan tersendiri, karena ini juga disebabkan oleh berbagai macam alasan, seperti tingkat kesulitan kaidah bahasa Arab itu sendiri, ketidaksesuaian antara contoh-contoh kaidah yang diajarakan dengan kenyataan sehari-hari yang dibutuhkan (seperti kaidah istighol), dan cara pengajaran kaidah yang tidak efektif, misalnya kaidah dibelajarkan dengan cara menghafal semata.

Faktor asumsi-asumsi yang salah biasanya terjadi pada pemahaman awal suatu konsep kebahasaan. Misalnya saja, pelajaran memahami bahwa kata benda yang tidak diakhiri denga $t a$ ' marbuthah adalah mudzakar. Asumsi dasar ini kemudian teraplikasikan ketika menggunakan kata serupa tetapi termasuk muannast majazi, seperti kata-kata: رب, سوق, شمس dan sebagainya.

Terlepas dari semua itu, banyak faktor yang menjadi sumber kesalahan pelajar dalam berbahasa. Diantaranya adalah situasi dan kondisi belajar yang tidak kondusif, ketidak sesuaian tujuan umum maupun khusus yang dirumuskan, tingkat kesulitan materi, metode penyajian dan sistematika buku ajar yang tidak releven, metode guru dalam pembelajaran bahasa yang tidak cocok, bahasa guru atau dosen itu sendiri yang belum benar berikut model interaksi antara guru-siswa yang tidak komunikatif.

Dengan demikian faktor-faktor yang mempengaruhi siswa atau mahasiswa yang mengalami kesalahan berbahasa itu sangat komplek dan multidimensional, baik bersifat lingustic, psikologis, sosiologis, maupun pedagosis dan edukasional.

\section{Signifikasi Analisis Kesalahan Berbahasa}

Kesalahan berbahasa dapat diklasifikasikan menjadi : ${ }^{8}$

\footnotetext{
${ }^{8}$ Hery Guntur Tarigan, Pengajaran analisis kesalahan berbahasa, (Bandung: Angkasa, 2011), h. 48-49
} 
1. Berdasarkan tatanan linguistik, kesalahan berbahasa diklasifikasikan menjadi: kesalahan berbahasa pada bidang fonologi, morfologi, sintaksis (frasa, klausa, kalimat), semantik, dan wacana.

2. Berdasarkan kegiatan berbahasa atau keterampilan berbahasa dapat diklasifikasikan menjadi kesalahan berbahasa dalam menyimak, berbicara, membaca, dan menulis.

3. Berdasarkan sarana atau jenis bahasa yang digunakan dapat berwujud kesalahan berbahasa secara lisan dan secara tertulis.

4. Berdasarkan penyebab kesalahan tersebut terjadi dapat diklasifikasikan menjadi kesalahan berbahasa karena pengajaran dan kesalahan berbahasa karena interferensi.

5. Kesalahan berbahasa berdasarkan frekuensi terjadinya dapat diklasifikasikan atas kesalahan berbahasa yang paling sering, sering, sedang, kurang, dan jarang. ${ }^{9}$

Sedangkan ragam kesalahan atau taksonomi berbahasa dapat diklasifikasikan menjadi empat yaitu :

1. Taksonomi segi linguistic

2. Taksonomi siasat permukaan

3. Taksonomi komparatif
4. Taksonomi efek komunikatif. ${ }^{10}$

Taksonomi tersebut mengklasifikasikan kesalahan-kesalahan berbahasa berdasarkan komponen linguistic atau unsur-unsur tertentu yang dipengaruhi oleh kesalahan atau berdasarkan keduanya.

Adapun komponen dalam bahasa diantaranya mencakup :

\section{a) Fonologi}

Sebelum menganalisis data kesalahan berbahasa sesuai klasifikasinya, ada baiknya jika disajikan terlabih dahulu istilah dan pengertian dan klasifikasi dalam kajian linguistik tersebut. Pada penyajian data pertama, penulis mengklasifikasi contoh kesalahan berbahasa dalam tinjauan fonologi. Secara etimologi, kata fonologi terambil dari kata fon yaitu bunyi, dan logi yaitu ilmu. Maksudnya, fonologi adalah salah satu bidang kajian linguistik yang mempelajari, menganalisis, dan membicakan runtunan bunyi-bunyi bahasa berkaitan dengan fenomena masyarakat jawa yang kesulitan dalam pengucapan al-fatihah الفاتحة meski mereka tahu penulisan kata tersebut, namun memang ternyata orang jawa, terutama kalangan usia lanjut sulit melafalakan huruf zyang berada di tengah kata. Maka berbicara kata الفاتحة menjadi ada sebagian yang berhujjah, bahwa kesalahan pengejaan itu dipengaruhi ejaan lama bahasa Indonesia. 
Namun ada juga yang beralasan lain. Semua itu memang perlu adanya penelitian khusus.

\section{b) Morfologi}

Morfologi merupakan bagian dari linguistik yang berhubungan dengan kajian kata, struktur internalnya dan sebagian maknanya. Morfologi juga menyangkut bagaimana pengguna sebuah bahasa tertentu memahami kata-kata kompleksnya dan menemukan item-item laksikal yang baru. Karena morfologi berkaitan dengan bentuk-bentuk kata maka morfologi juga berhubunga dengan fonologi (yang menunjukan bagaimana kata dilafalkan), dan terkait pula dengan kajian leksikal karena pola-pola yang diteliti yang dikaji oleh morfologi digunakan untuk membentuk kata-kata baru. ${ }^{11}$

Lebih jauh, morfologi juga berhubungan dengan semantik karena memiliki kaitan dengan makna kata. Morfologi lebih banyak mengacu pada analisis unsur-unsur pembentuk kata. Sebagai perbandingan sederhana, seorang ahli farmasi (kimia) perlu memahami zat apa yang dapat yang bercampur dengan suatu zat tertentu untuk menghasilkan obat flu yang efektif. Sama halnya seorang ahli linguistik bahasa Arab perlu

${ }^{11}$ Ali Khouli, Ilmu Lughah (Darul Falah: yordania 2007 ), h. 26 memahami imbuan apa yang dapat direkatkan dengan suatu kata tertentu untuk menghasilakan kata yang benar. ${ }^{12}$

\section{Kesalahan Berbahasa Arab Pada Level Fonologi Dan Morfologi}

Pada bagan ini, kami sengaja menggabung data kesalahan berbahasa dalam tinjauan morfologi dan sintaksis. Selain alasan efesien, kedua kajian lingustik ini memang mengarah pada gramatikal bahasa. Morfologi atau ilmu sharraf morfologi dan ilmu bunyi sintaksis atau semantic ilmu membahas klasifikasi morfem, macammacamnya, makna dan fungsinya.

Sedangkan sintaksis atau ilmu nahwu membahas seputar hukum dan kedudukan kata yang terdapat dalam kalimat atau teks, pembagian kalimat dan sebagainya. Kami akan memaparkan kesalahan-kesalahan para pelajar dalam perspektif gramatikal bahasa Arab, baik dari tinjauan morfemnya, juga dari kedudukan kata dalam kalimat atau teks bahasa Arab. ${ }^{13}$

a. Pertama, kata ma aharru asy-syahr ( ما أحر (الثهر) dengan men-dammah-kan huruf (ر) adalah sebuah kesalahan. Yang benar harus di-fathah-kan. Sengaja penulis mengarsipkan contoh tersebut. Karena kesalahan ini merupakan fenomena cikalbakal perintisan ilmu bahasa Arab;

\footnotetext{
${ }^{12}$ Ibid, h. 80

${ }^{13}$ Ali Khouli, Ilmu Lughah..., h. 191
} 
menjadi salah satu indikator munculnya ilmu Nahwu. Sebagaimana dilakoni oleh Abu Aswad Adduali dan putrinya.

b. Pada kalimat Nabhats maudu'al jadid( نبحث موضوع الجديد), dalam kaidah ilmu Nahwu, kalimat tersebut disebut na'at man'ut, atau penyifatan. Na'at adalah sifat, sedangkan man'ut adalah yang disifati. Kata (الجديد) menjadi sifat, sedangkan (موضوع) adalah yang disifati. Dalam kaidahnya, kata sifat harus mengikuti kata yang disifati, pada semua aspeknya. Jika kata yang disifati mudzakar, maka sifatnya juga harus mudzakar, jika kata yang disifati nakirah, demikian juga sifatnya harus dari nomina nakirat. Dalam kalimat di atas, kata (موضوع) adalah nomina mudzakkar yang nakirat, maka seharusnya kata (الجديد) sebagai sifat harus juga nomina yang mudzakarnakirat. Maka yang benar susunan kalimat tersebut adalah Nabhats maudhu'an jadidan ( نبحث موضوعا جديدا). ${ }^{14}$

c. Kalimat Uridu ata'allamu ( أريد أتعلم) adalah kesalahan yang kerap kali dijumpai pelajar dalam menyusun kalimat Arab. Kalimat tersebut terdiri dari dua kata kerja: uridu (mau/ menginginkan), dan ata'allamu (saya belajar). Dalam kaidah bahasa Arab, dua kata kerja seperti itu harus dipisahkan dengan harf nasb (أن). maka kalimat tersebut seharusnya Uridu an ata'allama (أريد أن أتعلم).

Pada dasarnya, bahasa Arab adalah bahasa yang simpel. Perubahan katakatanya sangat sistematis. Dalam kata kerja, umpamanya, perhitungan waktu sangat sistematis. Tanpa harus ditambah kata penegasan waktu lampau, saat ini atau yang akan datang, dengan kaidah yang berlaku, seseorang sudah mafhum dengan waktu yang dimaksud penutur. Jika ingin mengatakan sudah melakukan sesuatu, penutur bahasa Arab tidak usah menambahkan kata sudah, sebagaimana bahasa Indonesia. Maka contoh pada kalimat Ana khalas akulu (أنا جلاص اكل ), yang maksudnya saya sudah makan, penutur cukup menggunakan fi'il madi dari kata (اكل), menjadi (اكلت).

Pada kalimat man yadribu anta ( من (يضرب أنت), itu juga salah. Yang benar adalah man yadribuka (من يضربك ). dalam kaidah nahwu dibedakan antara kata ganti yang menjadi subjek dan objek. Jika anta adalah kata ganti orang kedua mudzakar untuk subjek, maka $k a$ adalah kata ganti orang kedua mudzakar untuk kedudukan objek. 
Pada contoh kesalahan selanjutnya, berkaitan dengan kaidah bilangan (adad). Dalam kaidah bahasa Arab, dibedakan antara bilangan nominal dan bertingkat. Bilangan nominal satu, misalnya, berbeda dengan kata kesatu. Jika yang pertama wahidun, untuk mudzakar, wahidatun untuk muannas; maka bilangan bertingkatnya menjadi al-awwal dan al-ula. Maka kalimat di atas yang semula Ana talibul fasli wahid ( أنا طالب الفصل الواحد), yang benar adalah Ana talibul faslil awwali ( أناطالب (الفصل ألاول).

Contoh kesalahan penutur karena tidak mencermati kaidah bahasa Arab berkaitan syart dan jawabu alsyart. Selain itu, penutur kurang mencermati cara penggunaan antara fi'il madi dan mudari'. Untuk kalimat Anta tanjahu idza tata'allam ( أنت تتجه اذا تتعلم ), seharusnya Tanjahu idza ta'allamta (تنجح اذا تعلمت (), atau in tata'allam tanjah (ان تتعلم تتجح).

\section{Manfaat Dan Tujuan Diadakannya} Analisis Bahasa

Dengan diadakannya analisis kesalahan berbahasa dapat membantu guru untuk mengetahui jenis kesalahan yang disebut, daerah kesalahan, sifat kesalahan, sumber kesalahan, serta penyebab kesalahan. Bila guru telah menemukan kesalahan-kesalahan, guru dapat mengubah metode dan teknik mengajar yang digunakan, dapat menekankan aspek bahasa yang perlu diperjelas, dapat menyusun rencana pengajaran remedial, dan dapat menyusun program pengajaran bahasa itu sendiri. Dengan demikian jelas bahwa antara analisis kesalahan dan bidang kajian yang lain, misalnya pengelolaan kelas, interaksi belajarmengajar, perencanaan pengajaran, pengajaran remedial, penyusunan ujian bahasa, dan bahkan pemberian pekerjaan rumah ada hubungan timbal balik. khusus untuk guru, analisis kesalahan dapat digunakan untuk : ${ }^{15}$

1. Menentukan urutan sajian.

2. Menentukan penekanan-penekanan dalam penjelasan dan latihan.

3. Memperbaiki pengajaran remedial.

4. Memilih butir-butir yang tepat untuk mengevaluasi penggunaan bahasa siswa.

\section{Metode Pembelajaran Yang Sesuai Untuk Mengatasi Masalah}

Metode pembelajaran bahasa Arab tradisional adalah metode pembelajaran yang terfokus pada "bahasa sebagai budaya ilmu" sehingga belajar bahasa Arab berarti belajar secara mendalam tentang seluk beluk ilmu bahasa Arab, baik aspek gramatikal/sintaksis

\footnotetext{
${ }^{15}$ Aunurrohman, Belajar..., h. 162
} 
(Qowaid nahwu), morfem/morfologi (Qowaid as-sharaf) ataupun sastra (Arab).

Metode yang berkembang dan masyhur digunakan untuk tujuan tersebut adalah Metode qowaid dan tarjamah. Metode tersebut mampu bertahan beberapa abad, bahkan sampai sekarang pesantren-pesantren di Indonesia, khususnya pesantren salafiah masih menerapkan metode tersebut. Hal ini didasarkan pada hal-hal sebagai berikut: pertama, tujuan pengajaran bahasa Arab tampaknya pada aspek budaya/ilmu, terutama nahwu dan ilmu sharaf. Kedua kemampuan ilmu nahwu dianggap sebagai syarat mutlak sebagai alat untuk memahami teks/kata bahasa Arab klasik yang tidak memakai harakat, dan tanda baca lainnya. Ketiga, bidang tersebut merupakan tradisi turun menurun, sehingga kemampuan dibidang itu memberikan "rasa percaya diri (gengsi) tersendiri di kalangan mereka.

Adapun metode yang tepat digunakan dalam meminimalkan kesalahan berbahasa yaitu metode Qowa'id Dan Tarjamah (Tariiqatul Al Qowaid Wa Tarjamah). Penerapan metode ini lebih cocok jika tujuan pengajaran bahasa Arab adalah sebagai kebudayaan, yaitu untuk mengetahui nilai sastra yang tinggi dan untuk memiliki kemampuan kognitif yang terlatih dalam menghafal teks-teks serta memahami apa yang terkandung di dalam tulisan-tulisan atau buku-buku teks, terutama buku Arab klasik. Ciri metode ini adalah: ${ }^{16}$

1. Peserta didik diajarkan membaca secara detail dan mendalam tentang teks-teks atau naskah pemikiran yang ditulis oleh para tokoh pakar dalam berbagai bidang ilmu pada masala lalu baik berupa sya'ir, naskah (prosa), kata mutiara (alhikmah), maupun kiasan-kiasan (amtsal).

2. Penghayatan yang mendalam dan rinci terhadap bacaan sehingga peserta didik memiliki perasaan koneksitas terhadap nilai sastra yang terkandung di dalam bacaan. (bahasa Arab- bahasa ibu).

3. Menitikberatkan pada kaidah gramatikal (Qowa'id Nahwu/Sharaf) untuk menghafal dan memahami isi bacaan.

4. Memberikan perhatian besar pada katakata kunci dalam menerjemah, seperti bentuk kata kiasan, sinonim, dan meminta peserta didik menganalisi dengan kaidah gramatikal yang sudah diajarkannya (mampu menerjemah bahasa ibu ke dalam Bahasa Arab)

5. Peserta didik diajarkan menulis karangan dengan gaya bahasa yang serupa / mirip, dengan gaya bahasa yang dipakai para pakar seperti pada bacaan yang telah dipelajarinya.

Selain ciri-ciri di atas, masih ada cirriciri lain pernggunaan metode Nahwu wa 
Tarjamah (tata bahasa dan terjemah) yang bisa dijelaskan, seperti yang dirangkum Jack C. Richards dan Theodore S Rodgers, dalam Azhar Arsyad, yaitu sebagai beriku:

1. Tujuan telaah bahasa asing adalah mempelajari suatu bahasa agar dapat membaca susastranya atau agar dapat menarik keuntungan dari disiplin mental dan perkembangan intelektual yang timbul dari telaah bahasa asing itu. Terjemahan tata bahasa adalah suatu cara menelaah bahasa yang mendekati bahasa tersebut pertamatama melalui kaidah-kaidah tata bahasanya secara terperinci, diikuti oleh penerapan pengetahuan ini pada tugas penerjemahan kalimat-kalimat dan teks-teks ke dalam dan dari bahasa sassaran. Oleh karena itu, pembelajaran bahasa dipandang sebagai yang terdiri dari upaya yang melebihi serta memanipulasi morfologi dan sintaksis bahasa asing tersebut. Bahasa pertama diperlakukan sebagai sistem acuan dalam pemerolehan bahasa kedua.

2. Membaca dan menulis merupakan fokus utama atau sasaran pokok, bahkan sering tidak ada perhatian sistemik pada belajar berbicara dan menyimak.

3. Pemilihan kosakata semata-mata didasarkan pada teks-teks bacaan yang digunakan, dan kata-kata yang diajarkan melalui daftar-daftar kata dwibahasa, telaah kamus dan hafalan. Dalam teks terjemahan tata bahasa yang khas, kaidah-kaidah tata bahasa pun disajikan dan diilustrasikan, suatu daftar butir-butir kosakata disajikan dengan padanan-padanan terjemahannya, dan latihan-latihan terjemahan ditetapkan.

4. Kalimat merupakan unit dasar pengajaran dan praktik/latihan bahasa. Kebanyakan dari jam pelajaran diperuntukkan bagi penerjemahan kalimat-kalimat ke dan bahasa sasaran dan justru terfokus terhadap kalimat inilah yang merupakan cirri khusus metode ini.

5. Kecermatan dan ketepatan sangat ditentukan. Para siswa diharapkan dapat mencapai norma-norma atau standar yang tinggi dalam terjemahan, karena prioritas utama yang diberikan pada norma-norma ketepan dan kecermatan yang tinggi yang merupakan prasyarat bagi kelulusun sejumlah besra ujian tulis formal yang berkembang selama abad ini.

6. Tata bahasa diajarkan secara deduktif, dengan penyajian dan pengkajian kaidahkaidah tata bahasa, yang kemudian dipraktikkan melalui latihan-latihan terjemahan. Dalam kebanyakan teks terjemahan tata bahasa, suatu silabus diikuti dengan baik demi pengurutan butir-butir tata bahasa di seleruh teks dan ada upaya untuk mengajarkan tata bahasa 
dengan dan dalam suatu cara yang tersusun rapi dan sistemik.

7. Bahasa asli/ibu siswa merupakan media pengajaran. Bahasa tersebut dipakai untuk menjelaskan butir-butir atau hal baru dan untuk memudahkan pembuatan perbandingan antara bahasa asing dan bahasa ibu siswa.

Kedua kemampuan ilmu nahwu dianggap sebagai syarat mutlak sebagai alat untuk memahami teks/kata bahasa Arab klasik yang tidak memakai harakat, dan tanda baca lainnya. Ketiga, bidang tersebut merupakan tradisi turun temurun, sehingga kemampuan di bidang itu memberikan "rasa percaya diri (gengsi) tersendiri di kalangan mereka. ${ }^{17}$

\section{Daftar Pustaka}

Abdul Chaer, Linguistik Umum, (Ja karta: Rineka Cipta 2004)

Ahmad Muhammad Qaddur, Buhuts fi alIsytisyrãq wa al-Lughah, (Muassasah al-Risalah, Beirut, cet.I 1996)

Ali Khouli, Ilmu Lughah (Darul Falah: yordania 2007 )

Aunurrohman, Belajar dan Pembelajaran, (Bandung: Alfabeta 2011)

Azhar Arsyad, , Bahasa Arab dan Metode Pengajarannya, (Yogyakarta:Pusta

17 Arsyad, Azhar., , Bahasa Arab dan Metode Pengajarannya, (Yogyakarta:Pustaka Pelajar. 2003) h.14 ka Pelajar. 2003)

Hery Guntur Tarigan, Pengajaran analisis kesalahan berbahasa, (Bandung: Angkasa, 2011)

Muhamad Ramlan, Ilmu Bahasa Indonesia, (Yogyakarta: CV. Karyo, 1987)

Nanik Setyawati, Analisis Kesalahan Berbahasa Indonesia, (Surakarta: Yuma pustaka, 2010) 
22 | II-Fathlin Vol. 1 Edisi Januari-Juni 2018 